\title{
ANALISIS KEPEMILIKAN ASING DAN STRATEGI PENGENDALIAN DOMINASINYA DALAM PEREKONOMIAN INDONESIA
}

\author{
Ahmad Zafrullah Tayibnapis \\ Fakultas Bisnis dan Ekonomika, Universitas Surabaya
}

\begin{abstract}
Investasi kepemilikan asing ternyata cukup dominan dalam perekonomian Indonesia, khususnya pada sektorsektor ekonomi strategis. Dominasi investasi kepemilikan asing di Indonesia sangat mengganggu kedaulatan ekonomi dan perwujudan demokrasi ekonomi sebagaimana termaktub dalam Pasal 33 Ayat (3) UUD 1945 yang secara jelas menyebutkan bahwa bumi, isi, dan kekayaan alam yang terkandung di dalamnya dikuasai oleh negara untuk sebesar-besar kemakmuran rakyat. Basis kulturalis bangsa Indonesia adalah kekeluargaan dan kolektivisme, ini berarti liberalisme sangat tidak tepat untuk diterapkan di Indonesia.
\end{abstract}

Keywords: Investasi kepemilikan asing, Sektor-sektor ekonomi strategis

\section{PENDAHULUAN}

Dominasi pihak asing kini semakin meluas dan menyebar pada sektor-sektor strategis perekonomian Indonesia, seperti keuangan, energi dan sumberdaya mineral, telekomunikasi, dan perkebunan. Per Maret 2011 pihak asing telah menguasai 50,6\% aset perbankan nasional, ini berarti sekitar $\mathrm{Rp}$. 1.551 triliun dari jumlah aset perbankan Rp. 3.065 triliun dikuasai asing. Secara perlahan porsi kepemilikan asing terus bertambah, mengingat per Juni 2008 kepemilikan asing baru mencapai 47,02\%. Hanya 15\% bank yang menguasai pangsa $85 \%$, dan sebagian sudah dimiliki asing. Dari jumlah 121 bank umum, kepemilikan asing ada 47 bank dengan porsi bervariasi (Mirza Adityaswarsa, Kompas, 10 Juni 2011).

Tak hanya perbankan, asuransi juga didominasi asing, hal ini dapat dicermati pada 45 perusahaan asuransi jiwa yang beroperasi di Indonesia, ternyata tak sampai setengahnya yang murni milik Indonesia. Kalau dikelompokkan, dari asuransi jiwa yang ekuitasnya di atas Rp. 75 miliar hampir semuanya usaha patungan. Dari sisi perolehan premi, lima besarnya adalah perusahaan asing. Hal itu tak terlepas dari aturan pemerintah yang sangat liberal, memungkinkan pihak asing memiliki sampai $99 \%$ saham perbankan dan $80 \%$ saham perusahaan asuransi.
Pasar modal juga demikian, yakni jumlah kepemilikan investor asing 60-70\% dari semua saham perusahaan yang dicatatkan dan diperdagangkan di Bursa Efek Indonesia. Pada Badan Usaha Milik Negara (BUMN) pun demikian, mengingat semua BUMN yang telah diprivatisasi ternyata kepemilikan asing sudah mencapai $60 \%$. Lebih tragis lagi di sektor minyak dan gas, yaitu porsi operator minyak nasional hanya sekitar 25\%, dan selebihnya $75 \%$ dikuasai pihak asing (Zaenal Abidin, Kompas, 20 Juni 2011).

Dalam 13 tahun era reformasi, utang luar negeri terus bertambah. Di akhir era Soeharto, utang luar negeri Indonesia 54 miliar dollar Amerika Serikat, namun posisi utang luar negeri sampai April 2011 sekitar Rp. 128,6 miliar dollar Amerika Serikat dengan sifat utang berbunga jauh lebih tinggi, $11 \%$ per tahun, berjangka lebih pendek (5 10 tahun), dan bersumber dari pasar modal (Umar Juoro, Kompas, 2 September 2011).

Perekonomian Indonesia saat ini tidaklah terlepas dari ketidakpastian perekonomian di Amerika Serikat dan Eropa. Sekalipun perekonomian Indonesia sangat dicirikan oleh ekonomi domestik, dengan ekspor hanya sekitar 28\% dari Produk Domestik Bruto, dan rekan dagang utama adalah Jepang dan China, Amerika Serikat dan Eropa masih punya pengaruh penting 
dalam perekonomian Indonesia. Apalagi rekan dagang utama Indonesia di Asia lebih bergantung pada perekonomian Amerika Serikat dan Eropa, ini berarti ketidakpastian ekonomi dunia sangat berpengaruh pada perekonomian Indonesia yang saat ini tersandera oleh dominasi kepemilikan asing pada sektor-sektor strategis perekonomian.

Patut dicermati bahwa Indonesia merupakan salah satu dari beberapa negara kawasan Amerika Latin dan Asia sebagai sasaran masuknya dana asing. Di satu sisi dana asing sangat dibutuhkan oleh Indonesia, namun di sisi lain bisa menjadi bumerang apabila tidak hati-hati karena hot money dapat membuat perekonomian Indonesia kolaps apabila terjadi titik balik arus dana asing. Seyogyanya pemerintah memberlakukan sebuah kebijakan untuk mengawasi dana asing yang masuk sebagaimana dilakukan Thailand dan Brazil yang memberlakukan sistem pajak bagi para pelaku yang membawa dana asing atau diberi aturan dengan memberikan para investor asing jangka waktu selama kurun waktu tertentu guna menahan capital inflow agar bertahan lebih lama dan lebih baik lagi kalau dialihkan ke sektor riil.

Sebagaimana diketahui bahwa dua mazhab utama yang perlu diketahui terkait kepemilikan asing untuk sektor ekonomi, yaitu aliran kepemilikan dan aliran manfaat. Asas manfaat lebih menekankan manfaat yang dapat diraih oleh seluruh pemangku kepentingan, termasuk di dalamnya rakyat Indonesia. Asas ini tidak memedulikan siapa pengelola, bahkan pemilik dari perusahaan tersebut selama perusahaan tersebut bisa memberikan manfaat sebesar-besarnya. Sebaliknya, asas kepemilikan sangat peduli terhadap siapa pemilik dan pengelolanya. Asumsi yang mendasari, kalau pemiliknya warga negara setempat, mereka akan lebih peduli terhadap seluruh pemangku kepentingan daripada jika pemilik pihak asing.

Dominasi kepemilikan asing dalam perekonomian Indonesia patut dipertanyakan keberadaannya, mengingat perolehan laba tentu dibawa kembali ke negara asal dan berpotensi bubble economy karena derasnya dana asing masuk ke pasar modal. Belum lagi ancaman over heating yang bisa memicu tekanan inflasi dan penarikan dana secara tiba-tiba dalam jumlah besar dapat membuat perekonomian Indonesia menjadi krisis sebagaimana pernah terjadi pada 1977-1998.

Beranjak dari latar belakang maka permasalahan dalam penelitian ini adalah "bagaimanakah keberadaan kepemilikan asing dan strategi pengendalian dominasinya dalam perekonomian Indonesia, khususnya pada sektor-sektor ekonomi strategis?"

\section{METODE PENELITIAN}

Penelitian ini termasuk dalam kategori deskriptif karena menganalisis kondisi eksisting, masalah dan fenomena dominasi kepemilikan asing dalam perekonomian Indonesia, khususnya pada sektor-sektor ekonomi strategis, seperti perbankan, perdagangan retail, pertambangan dan mineral, kelapa sawit, operator telekomunikasi dan lain-lain.

Selanjutnya bila ditinjau dari sisi jenisnya termasuk penelitian kualitatif karena metode yang digunakan dalam penelitian ini tertuju pada kondisi obyek yang alamiah, dan penelitian merupakan instrumen kunci serta teknik pengumpulan data dilakukan secara triangulasi. Analisis data bersifat induktif, dan lebih menekankan makna daripada generalisasi.

Data yang digunakan dalam penelitian ini adalah data sekunder dan primer dalam rangka memperoleh suatu hasil analisis yang utuh. Data sekunder adalah data yang diperoleh dari instansi pemerintah yang relevan dan berwenang di Indonesia, yaitu : (1) Badan Pusat Statistik Republik Indonesia; (2) BAPPENAS; (3) Bank Indonesia; (4) Badan Penanaman Modal Republik Indonesia, (5) Kementerian ESDM; (6) Bursa Efek Indonesia-IDX; (7) Kementerian Kehutanan; (8) Kementerian Pertanian; dan (9) BISINFOCUS. Selanjutnya data primer diperoleh dari informasi pelaku usaha yang dimiliki asing, seperti perbankan, SBI,utang luar negeri, tambang batubara, kelapa sawit, perdagangan retail, operator telekomunikasi dan perminyakan.

Dalam upaya mengurangi dominasi kepemilikan asing dalam perekonomian 
Indonesia digunakan SWOT Analysis, yakni menentukan: (1) Kekuatan (Strength) ; (2) Kelemahan (Weakness); Peluang (Opportunity); dan (4) Ancaman (Threats). Secara teknis, data yang telah dikumpulkan selanjutnya dikategorikan sesuai dengan keperluan dalam bentuk tabel, berikutnya dianalisis berdasarkan hasil SWOT yang dilakukan secara obyektif.

Analisis lingkungan internal dan eksternal yang dilakukan menjadi landasan kritis dalam merancang strategi, dan dapat dikelompokkan ke dalam empat kelompok strategi, yakni :

1. Strategi mengoptimalkan kekuatan untuk memanfaatkan peluang.

2. Strategi menggunakan kekuatan untuk mencegah dan mengatasi ancaman.

3. Strategi mengurangi kelemahan untuk memanfaatkan peluang.

4. Strategi mengurangi kelemahan untuk mencegah dan mengatasi ancaman.

\section{KAJIAN PUSTAKA}

Patut disimak bahwa kisi-kisi ekonomi sebenarnya sudah jelas termaktub dalam Pancasila dan UUD 1945. Atas dasar itu maka minimal terdapat 2 aspek yang paling utama dari kisi pembangunan ekonomi, yakni mewujudkan dan menjamin kesejahteraan bagi seluruh rakyat Indonesia (keadilan sosial), serta menjamin kedaulatan di bidang ekonomi (kedaulatan ekonomi). Karena itulah, asas pembangunan ekonomi adalah demokrasi ekonomi, sebagaimana diamanatkan dalam Pasal 33 UUD 1945.

Kesejahteraan ekonomi dan kedaulatan ekonomi adalah menyangkut ideologi. Demokrasi ekonomi tidak harus berarti anti asing, mengingat dalam era global, hubungan kerjasama merupakan suatu keniscayaan. Hanya saja kerjasama senantiasa dibangun di atas dan berdasar atas ideologi yang jelas dan kukuh. Dengan demikian, investor asing tetap dibutuhkan, namun hanya sebagai pelengkap saja setelah prioritas keberpihakan ditujukan pada upaya membangun kedaulatan ekonomi sesuai asas demokrasi ekonomi.

\section{HASIL PENELITIAN}

Per Maret 2011 pihak asing telah menguasai $50,6 \%$ aset perbankan nasional atau sekitar Rp. 1.551 triliun dari aset perbankan Rp. 3.065 triliun dikuasai asing. Secara perlahan porsi kepemilikan asing terus bertambah, mengingat per Juni 2008 kepemilikan asing sekitar 47,02\%. Hanya 15 bank yang menguasai pangsa $85 \%$, dan sebagian sudah dimiliki asing. Dari jumlah 121 bank umum, kepemilikan asing ada pada 47 bank dengan porsi bervariasi. Pangsa papar kredit cabang bank asing, bank campuran, dan bank swasta milik asing sudah sekitar $47 \%$.

Posisi kenaikan bank asing di Indonesia senantiasa meningkat karena keuntungan yang diraih sangat tinggi, bahkan tertinggi di ASEAN. Net Internet Margin (NIM) Perbankan di Indonesia rata-rata lebih dari $6 \%$, sedangkan Malaysia dan Singapura hanya berkisar 3,17\% dan 2,79\%. Keuntungan yang cukup besar juga diraih bank domestik yang dikuasai investor asing, seperti CIMB Niaga Bank dan Bank Danamon pada akhir tahun 2010 memperoleh NIM 6,4\% dan 9,13\%, di atas rata-rata bank umum karena kemampuannya menciptakan efisiensi. Jadi dapat dikemukakan bahwa bank asing di Indonesia memang mempunyai kinerja lebih baik dibandingkan bank domestik, dan cenderung mencari keuntungan melalui fee based income dibandingkan berat pengeluaran kredit sehingga kurang berperan dalam pertumbuhan ekonomi. Tidak mengherankan kalau investor akan cenderung "memborong" saham perbankan Indonesia karena return on equity-nya tinggi.

Leluasanya pihak asing memiliki saham sampai 99\% berdasarkan Peraturan Pemerintah Nomor 29 Tahun 1999, khususnya Pasal 3. Dampak kebijakan itu membuat kepemilikan pihak asing terus meningkat, hal ini artinya sama saja dengan menyerahkan kondisi perbankan tergantung pada asing dan Bank Indonesia praktis tidak bisa mengontrol pemanfaatan dana di bank asing, karena berada di luar yurisdiksinya. Sementara itu di negara lain tidak sebebas seperti di Indonesia, katakanlah Amerika Serikat yang melakukan kepemilikan saham 
bank per pihak (tidak ada mayoritas). Malaysia hanya membatasi $30 \%$ saja, begitu pula di Singapura, pemilikan bank asing sampai 5\%, 10\%, dan 20\% harus izin negara. Selanjutnya di Filipina, pemilikan bank asing sampai 100\% dibatasi hanya sampai 7 tahun dan setelah itu kepemilikan saham dikurangi. Thailand juga memberlakukan 10 tahun untuk pemilikan bank asing hingga 100\%. Jadi dapat dikatakan bahwa regulasi pemilikan bank oleh asing di Indonesia paling liberal dan pemerintah tampaknya masih memandang perlu memiliki pihak yang controlling share holder supaya ada yang bertanggung jawab kalau bank bermasalah.

Tabel 1

Cengkeraman Asing di Bank Nasional

\begin{tabular}{llll}
\hline No & \multicolumn{1}{c}{ Bank Nasional } & \multicolumn{1}{c}{$\begin{array}{c}\text { Kepemilikan Asing } \\
(\%)\end{array}$} & \multicolumn{1}{c}{ Lembaga Asing } \\
\hline $\mathbf{1}$ & ANK & 83 & Commonwealth Australia \\
$\mathbf{2}$ & Bank Ekonomi Raharja & 98,96 & HSBC - Hongkong \\
$\mathbf{3}$ & Bank Buana & 91 & UOB - Singapura \\
$\mathbf{4}$ & Hakim Internasional & 90 & ICBC - China \\
$\mathbf{5}$ & Bank Mestika Dharma & 80 & BHB Capital Berhad - \\
& & & Malaysia \\
$\mathbf{6}$ & Swadesi & 76 & Bank of India \\
$\mathbf{7}$ & Indomonex & 76 & Bank of India \\
$\mathbf{8}$ & Nusantara & 75,41 & Tokyo Mitsubishi - Jepang \\
$\mathbf{9}$ & BTPN & 71,6 & Texas Pacific - USA \\
$\mathbf{1 0}$ & Danamon & 67,86 & Temasek Holding - \\
& & & Singapura \\
$\mathbf{1 1}$ & CIMB Niaga & 77 & CIMB Group Sdm Bhd \\
$\mathbf{1 2}$ & Bumi Putera & 58,32 & The Abdul Daim - \\
& & & Malaysia \\
$\mathbf{1 3}$ & BII & 54,33 & Maybank - Malaysia \\
$\mathbf{1 4}$ & Permata & 44,51 & Standard Chartered Bank \\
& & & - UK \\
$\mathbf{1 5}$ & Panin & 35 & ANZ Bank - Australia \\
$\mathbf{1 6}$ & NISP & & OCBC-NISP, Singapura \\
\hline
\end{tabular}

Sumber : IDX dan berbagai sumber, 2011

Sebagaimana diketahui bahwa ada satu jenis investasi asing yang masih sedikit dipahami manfaatnya bagi perekonomian Indonesia, yaitu investasi asing dalam Sertifikat Bank Indonesia atau SBI. SBI adalah instrumen moneter Bank Indonesia (BI) yang digunakan untuk mengimplementasikan kebijakan moneternya. Ketika BI merasa pertumbuhan ekonomi terlalu cepat (ancaman inflasi meningkat atau keadaan likuiditas sistim finansial dianggap selalu tinggi), maka BI akan menerapkan kebijakan moneter yang lebih ketat. Biasanya diartikan BI Rate akan naik, yang disertai kenaikan suku bunga lain.
Investasi asing di SBI terbukti telah menambah beban kebijakan moneter BI dengan cukup signifikan, padahal kenyataan bahwa investasi asing yang masuk ke SBI tidak ada hubungannya dengan pengendalian keadaan likuiditas dalam negeri bila uang dari luar negeri tersebut masuk ke Indonesia dengan tujuan hanya untuk dibelikan SBI. Sementara manfaat uang tersebut untuk perekonomian Indonesia juga hampir tidak ada karena uang tersebut diserap Bank Indonesia dan akan mengendap terus di BI sampai dicairkan kembali oleh investor asing yang bersangkutan.

Sebagai ilustrasi, pada Desember 2009 SBI Outstanding baru mencapai Rp. 256 
triliun dan pada Mei 2010 jumlah tersebut meningkat menjadi Rp. 326 triliun. Perkalian sederhana antara SBI Outstanding dan bunga SBI menunjukkan bahwa dalam periode Desember 2009 hingga Mei 2010 BI harus membayar bunga sekitar Rp. 9,6 triliun, ini berarti dalam satu tahun beban yang harus dibayar BI mencapai lebih dari Rp. 20 triliun. Selanjutnya perlu dicermati bahwa uang investor asing di SBI pada Desember 2009 mencapai Rp.44 triliun dan meningkat menjadi Rp.83 triliun pada April 2010, ini berarti dengan perkalian sederhana menunjukkan bahwa dalam periode tersebut bunga yang harus dibayar oleh BI untuk investor asing mencapai Rp. 1,58 triliun. Dana asing juga dipergunakan untuk menambah devisa negara (asumsi bahwa seluruh dollar AS yang masuk diserap BI). Jika diasumsikan devisa yang dihasilkan langsung diinvestasikan BI dalam US-Treasury (Obligasi Pemerintah AS) yang akan jatuh tempo dalam 5 tahun dengan imbal hasil 2,1 - 2,5\% pada periode tersebut, maka bunga yang dihasilkan akan mencapai Rp.0,59 triliun sampai jatuh tempo.

Beranjak dari ilustrasi tersebut maka selama periode Desember 2009 - April 2010 secara neto investasi asing di SBI telah menimbulkan beban tambahan kepada BI sekitar Rp.0,99 triliun atau dengan kata lain, pemerintah melalui BI memberikan uang ke investor asing sebesar itu untuk uang yang tidak dipergunakan. Belum lagi kalau ternyata BI menginvestasikan dana asing tersebut ke dalam instrumen dengan maturity lebih pendek maka kewajiban BI pasti di atas Rp.0,99 triliun, lebih celaka lagi kalau tidak diinvestasikan sama sekali.

Tabel 2

Operator Telekomunikasi di Indonesia

\begin{tabular}{|c|c|c|c|}
\hline No. & $\begin{array}{c}\text { Operator } \\
\text { Telekomunikasi }\end{array}$ & Domestik & Asing \\
\hline 1 & $\begin{array}{l}\text { Telkomsel } \\
(\text { Asing }=35 \%)\end{array}$ & PT. Telkom 65\% & Sing Tel Mobile - Singapore $=35 \%$ \\
\hline 2 & $\begin{array}{l}\text { Hutchison (Tri) } \\
\text { (Asing }=60 \%)\end{array}$ & $\begin{array}{l}\text { PT. Charoen } \\
\text { Pokphand Group } \\
\text { Indonesia } 40 \%\end{array}$ & $\begin{array}{l}\text { Hutchison Whampoa }- \text { Hongkong = } \\
60 \%\end{array}$ \\
\hline 3 & $\begin{array}{l}\text { PT. Indosat } \\
\text { (Asing }= \\
70,38 \%)\end{array}$ & $\begin{array}{l}\text { Pemerintah RI = } \\
\text { 14,29\% } \\
\text { Publik }=15,33 \%\end{array}$ & $\begin{array}{l}\text { Skagen AS Entities - Norwegia } \\
=5,38 \% \\
\text { Q-Tel Asia - Datar }=65 \%\end{array}$ \\
\hline 4 & $\begin{array}{l}\text { PT. XL Axiata } \\
\text { (Asing }=80 \%)\end{array}$ & Publik $=20 \%$ & $\begin{array}{l}\text { Indocel Holding Sdm Bhd - } \\
\text { Malaysia }=66,7 \% \\
\text { Etisalat International Indonesia } \\
\text { Ltd - Uni Emirat Arab }=13,3 \%\end{array}$ \\
\hline 5 & $\begin{array}{l}\text { Natrindo (Axis) } \\
\text { (Asing }=95 \%)\end{array}$ & Perusahaan lokal 5\% & $\begin{array}{l}\text { Saudi Telecom Company - } \\
\text { Arab Saudi }=80,1 \% \\
\text { Maxis Communication - } \\
\text { Malaysia }=14,9 \%\end{array}$ \\
\hline
\end{tabular}

Sumber : Bursa Efek Indonesia, 2012, diolah kembali

Masuknya investor asing ke pasar selalu diikuti pula investor lokal sehingga harga saham dan IHSG juga meningkat sebaliknya, jika kekuatan asing ini lebih banyak melakukan penjualan, maka gerakan inipun akan diikuti investor lokal sehingga harga saham dan IHSG ikut mengalami koreksi signifikan. Tidak bisa dipungkiri bahwa investor asing memang menjadi motor penggerak naik- turunnya IHSG di pasar. Fakta itu selalu terjadi berulang-ulang.

Sebagai contoh, ketika IHSG memecahkan rekor baru dengan menutup perdagangan di titik $3.215,44$ pada 3 April 
2012, dana asing yang masuk ke pasar mencapai Rp. 1.228,32 triliun. Saat itu IHSG naik 49,37 poin atau setara dengan $1,19 \%$; di sisi lain, kapitalisasi pasar mencapai Rp. 3.964 triliun. Untuk mencapai kapitalisasi pasar sebesar Rp. 4.000 triliun agaknya bukan suatu hal yang tidak mungkin, dan hanya tinggal menunggu waktu saja.

Pengaruh kekuatan asing semakin jelas pada transaksi hari berikutnya, yaitu pada 4 April 2012, dimana nilai jual bersih pihak asing hanya sebesar Rp. 466,79 miliar. Akibatnya, IHSG juga terkoreksi sebesar 81,41 poin atau setara dengan 1,93\%. Mayoritas saham yang ditransaksi pada hari itu mengalami penurunan harga dan kapitalisasi pasar juga anjlok menjadi Rp. 3.892,88 triliun.

Besarnya pengaruh investor asing ini seharusnya kurang sehat bagi pelaku pasar di Indonesia. Sebab, hal itu mencipta situasi seolah-olah pasar selalu ditentukan oleh investor asing, sedangkan investor domestik seperti tidak berdaya melawan pengaruh tersebut. Bahkan, pelaku asing selalu berada di atas angin dalam aktivitas transaksi saham di BEI. Umumnya mereka tidak takut rugi dan tidak takut kehilangan momentum karena mereka lah yang memiliki momentum. Investor asing senantiasa memenangkan transaksi, dan bisa membeli saham di saat harga murah serta berhasil menjual di saat harga tinggi. Ini terjadi karena investor asing itu berperan sebagai penggerak pasar.

Selanjutnya juga menarik untuk disimak terkait kekuatan asing pada operator telekomunikasi di Indonesia akibat kecerobohan pemerintah dalam menterjemahkan privatisasi BUMN.
Masuknya investasi asing dalam sektor telekomunikasi sebenarnya akibat kebijakan privatisasi badan usaha milik negara pasca krisis ekonomi 1997-1998, dan campur tangan International Monetary Fund (IMF) dalam menetapkan arah kebijakan ekonomi Indonesia pada waktu itu.

Menyadari kesalahan masa lalu maka sekarang pemerintah tampaknya berupaya keras untuk membeli kembali saham-saham yang dimiliki perusahaan asing dalam rangka menjaga ketahanan nasional, khususnya di bidang telekomunikasi. PT. Indosat, Tbk berupaya melakukan buy back dari perusahaan telekomunikasi Qatar sebanyak 65\%, dan PT. Telkomsel dari perusahaan Telekomunika Sing Tel Mobile Singapura yang menguasai saham 35\%. Selain itu, di sektor swasta, Excelcomindo (XL Axiata) meski dipimpin Chief Executive Officer asal Indonesia, Hasrul Sulaimi, mayoritas didamai asing yakni Axiata Group Bernhad-Malaysia melalui Indocel Holding Sdm Bhd sebanyak 66,7\%; Emirates Telecommunications Corporation melalui Etisalat International Indonesia Ltd (13,3\%), dan publik 20\%. Patut dicermati bahwa XL baru membayar dividen setelah 10 tahun investor menanamkan modal, padahal kartu SIM aktif pada kuartal I - 2011 sekitar 243 juta kartu, dan angka ini sudah melebihi jumlah penduduk Indonesia yang mencapai 237,6 juta jiwa. Sementara itu Rapat Umum Pemegang Saham Tahunan XL tahun 2011 hanya menyetujui Rp. 911,48 miliar dari laba tahun 2010 sebesar Rp. 2,89 triliun untuk dividen, dan selebihnya Rp. 1,97 triliun untuk investasi. 
Tabel 3

Utang Luar Negeri Indonesia, 2000-2012

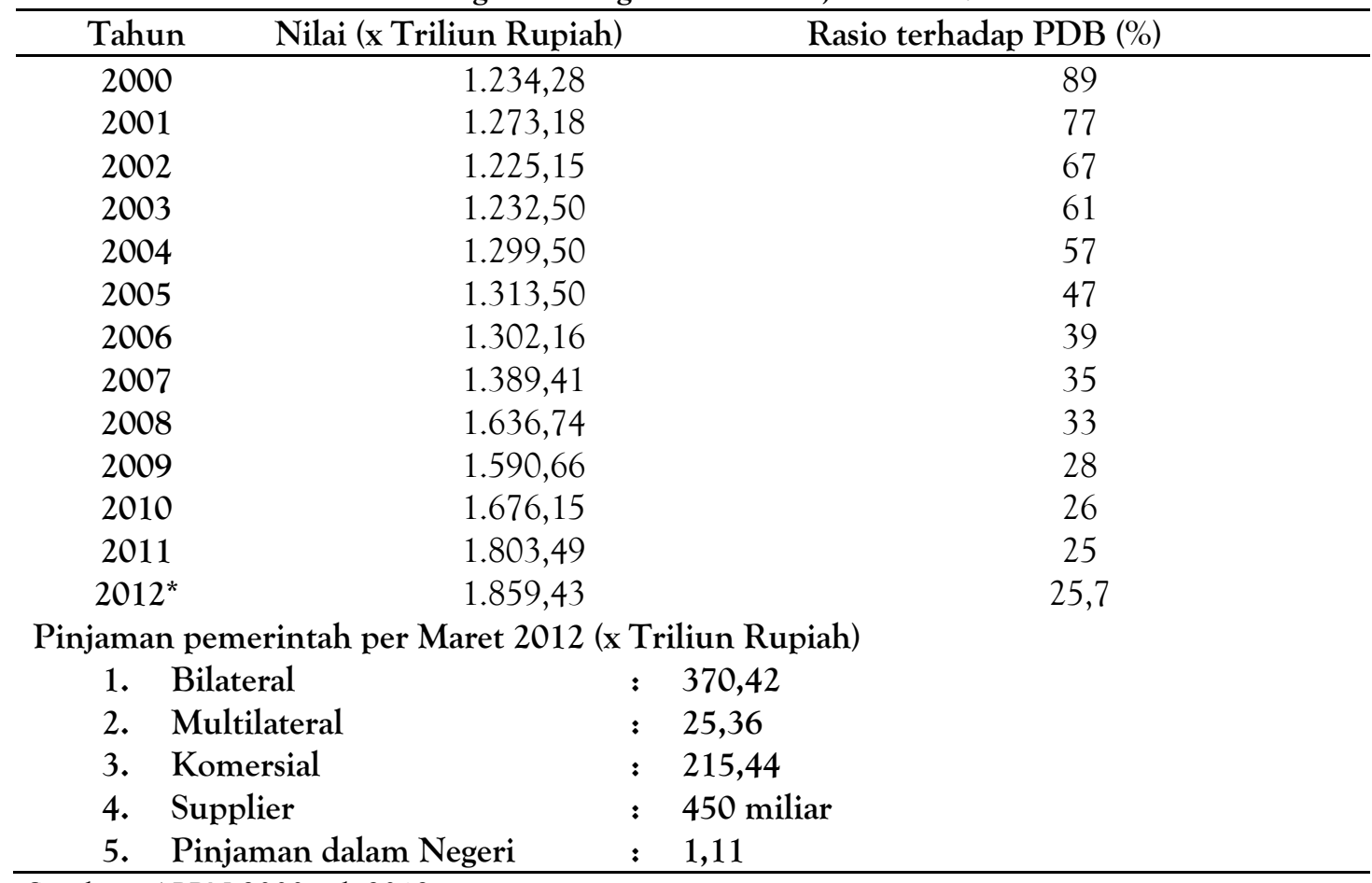

Sumber : APBN 2000 s.d. 2012

Utang Indonesia meningkat tajam dalam 5 tahun ini dan mencapai Rp. 1859,43 triliun pada Maret 2012. Utang negara yang menumpuk selama ini ditengarai tak produktif dan terjadi pemborosan anggaran belanja untuk elite dan birokrasi, bahkan tidak transparan dalam pengelolaannya.

Secara umum, pengelolaan keuangan Pemerintah di Indonesia berjalan baik, dan rambu-rambu defisit serta utang berada dalam kendali pesat. Defisit APBN selama bertahuntahun selalu berada di bawah 3\%, dan berhasil menjaga rasio utang terhadap PDB terus turun di level 25,7\% pada 2012. Bahkan, jika utang pemerintah yang berada di tangan Bank Indonesia dikeluarkan, maka rasio tersebut menjadi lebih kecil lagi dan mendekati angka 20\%. Pemerintah juga memiliki bantalan kas lumayan tebal, sekitar Rp. 200 triliun, baik yang berada di Bank Indonesia maupun di bank-bank umum. Ini berarti pemerintah memiliki cadangan dana untuk menutupi kebutuhan pelunasan utang yang jatuh tempo dalam satu tahun ataupun jika terjadi skor fall dalam penerimaan pada tahun berjalan. Kekuatan inilah yang perlu dijaga agar refinancing risk sebagaimana yang meledak di Yunani dapat dijaga pada tingkat rendah. Oleh karena itu pemerintah wajib memonitor tingkat risiko serendah mungkin. Jatuh tempo surat utang pemerintah harus diatur jangan sampai terjadi penumpukan jatuh tempo pada surat yang sama secara berlebihan. Kebijakan pengaturan utang yang dikenal dengan reprofiling perlu terus diusahakan, namun dengan pendekatan pasar. Begitu pula sumber utang pemerintah yang berasal dari defisit APBN perlu terus dijaga pada tingkat aman.

Indonesia sebagai negara kepulauan dengan jumlah penduduk yang besar $(236,7$ juta jiwa), dan wilayah yang membentang luas memiliki potensi sumber daya yang sangat besar tentu menumbuhkan dana yang sangat besar untuk melaksanakan pembangunan nasional, baik yang berasal dari dalam negeri maupun luar negeri. Pilihan untuk menanamkan modal di suatu negara bagi investor asing sangat dipengaruhi oleh banyak faktor, diantaranya masalah regulasi; stabilisasi ekonomi, politik dan sosial; perlindungan kepemilikan; perpajakan; infrastruktur, dan lain-lain. 
Tabel 4

Perkebunan Kelapa Sawit Milik Asing di Indonesia

\begin{tabular}{|c|c|c|c|c|}
\hline No. & Asal Negara & Perusahaan & $\begin{array}{c}\text { Luas Lahan } \\
\text { (x hektar) }\end{array}$ & Wilayah \\
\hline \multirow[t]{10}{*}{1} & Malaysia & Kumpulan & 220.204 & Riau, Jambi, Kalimantan \\
\hline & & Guthrie & & Selatan, Sumatera Selatan, \\
\hline & & Bernhard & & $\begin{array}{l}\text { Kalimantan Tengah, } \\
\text { Sulawesi Tengah, dan Aceh }\end{array}$ \\
\hline & & Kulim Bernhard & 97.263 & $\begin{array}{l}\text { Sumatera Barat, } \\
\text { Kalimantan Tengah, } \\
\text { Kalimantan Barat, } \\
\text { Sumatera Selatan }\end{array}$ \\
\hline & & Golden Hop & 96.00 & Kalimantan Barat \\
\hline & & Plantations & & \\
\hline & & Bernhard & & \\
\hline & & Kuala Lumpur & 91.170 & Riau, Kalimantan, Belitung \\
\hline & & Kepong & & \\
\hline & & Bernhard & & \\
\hline \multirow[t]{4}{*}{2} & Inggris & REA Holdings & 66.136 & Kalimantan Timur \\
\hline & & MP. Evans & 47.290 & Bangka, Kalimantan \\
\hline & & Group PLC & & $\begin{array}{l}\text { Timur, Sumatera Utara, } \\
\text { Bengkulu, Aceh }\end{array}$ \\
\hline & & $\begin{array}{l}\text { Anglo Estern } \\
\text { Plantations }\end{array}$ & 37.502 & $\begin{array}{l}\text { Bengkulu, Sumatera Utara, } \\
\text { Riau }\end{array}$ \\
\hline 3 & Belgia & SA. Slpef NV. & 65.993 & $\begin{array}{l}\text { Sumatera Utara, Bengkulu, } \\
\text { Aceh, Sumatera selatan }\end{array}$ \\
\hline 4 & Luxemburg & $\begin{array}{l}\text { Socfinasia SA. } \\
\text { Plantations } \\
\text { Nord Sumatra } \\
\text { Ltd. }\end{array}$ & 44.992 & Sumatera Utara \\
\hline 5 & Singapura & $\begin{array}{l}\text { Wilmar } \\
\text { Holdings }\end{array}$ & 198.285 & $\begin{array}{l}\text { Sumatera Selatan, } \\
\text { Sumatera Barat, } \\
\text { Kalimantan Barat, } \\
\text { Sumatera Utara, Riau }\end{array}$ \\
\hline 6 & $\begin{array}{l}\text { Amerika } \\
\text { Serikat }\end{array}$ & $\begin{array}{l}\text { Hindoli - } \\
\text { Cargill Inc. }\end{array}$ & 10.000 & Sumatera Selatan \\
\hline 7 & Sri Lanka & $\begin{array}{l}\text { Corson } \\
\text { Lumberbath \& } \\
\text { Co Ltd. }\end{array}$ & 27.500 & Kalimantan Tengah \\
\hline
\end{tabular}

Sumber : Kementrian Kehutanan RI, 2012

Besarnya modal yang masuk ke Indonesia ternyata membuat Bank Indonesia sulit menjalankan kebijakan moneter. Dengan besarnya modal portofolio yang mudah masuk dan keluar membuat nilai rupiah berfluktuasi, dalam arti apabila dana masuk bisa memperkuat rupiah, sedangkan dana keluar melemahkan rupiah. Bank Indonesia harus mensterilkan dana yang masuk dengan membeli dollar dengan rupiah. Akibatnya, uang beredar semakin besar dan Bank Indonesia tentu harus menarik kembali uang tersebut supaya tidak mendorong inflasi. Dengan tidak dilelangnya lagi SBI di bawah 9 bulan, maka penarikan dilakukan dengan deposit berjangka yang diperuntukkan hanya untuk bank dalam negeri.

Besarnya PMA juga mendorong peningkatan permintaan dollar untuk kebutuhan belanja modal dan modal kerja. 
Kredit dollar tumbuh sekitar 36\%, sementara itu dana pihak ketiga dalam dollar hanya tumbuh sekitar 3,5\%. Kesenjangan yang besar ini membuat BI harus berusaha keras menyediakan pasokan dollar, dan ada kecenderungan perusahaan semakin besar meminjam ke luar negeri. Patut dicermati manakala perusahaan meminjam jangka pendek untuk membiayai proyek jangka panjang.

Salah satu bidang investasi yang diminati PMA adalah perkebunan kelapa sawit yang membuat persaingan memperoleh lahan untuk perkebunan kelapa sawit semakin ketat di tengah perkembangan kenaikan kepemilikan konsesi oleh asing.

Saat ini, investor asing menguasai sedikitnya 5 juta hektar konsesi perkebunan kelapa sawit, dan sebagian besar merupakan kelompok-kelompok usaha perkebunan raksasa asal Malaysia, seperti Golden Hope dan Syme Dorbi. Investor asing masih terus mengincar konsesi lahan di Indonesia karena posisi yang strategis sebagai negara tropis dan masih memiliki sedikitnya 30 juta hektar kawasan hutan kritis yang berpotensi menjadi perkebunan kelapa sawit, karet, dan tebu.

Berdasarkan fakta yang ada, tingkat kepemilikan asing di perkebunan kelapa sawit Indonesia tergolong tinggi yakni mencapai $50 \%$ dari jumlah 9,5 juta hektar lahan. Jika tidak ada pengawasan secara ketat, kondisi ini berpotensi menghambat revitalisasi perkebunan, kesulitan untuk mengupayakan kenaikan upah petani, dan tidak dapat maksimal dalam menggerakkan perekonomian nasional. Ini berarti sudah saatnya pemerintah untuk menghentikan sementara ijin investasi di sektor perkebunan kelapa sawit dan karet oleh investor asing, dan selanjutnya membuka peluang kepada investor dalam negeri untuk menggarap 30 juta hektar perkebunan kelapa sawit agar ke depan Indonesia bisa memiliki kedaulatan di kelapa sawit.
Bidang investasi yang juga sangat diminati PMA adalah sektor - sektor ekonomi strategis, seperti minyak bumi, gas alam, batubara, dan lain-lain. Perusahaan tambang asing, terutama China dan India masuk menguasai tambang kecil dengan membiayai perusahaan-perusahaan tambang lokal yang kesulitan pendanaan. Dua negara ini sangat agresif mencari sumber daya batubara sebagai pengganti minyak di luar negeri, sementara cadangan migas dan tambangnya sengaja di simpan untuk kepentingan generasi mendatang.

Indonesia yang hanya memiliki cadangan batubara terbukti 4,3 miliar ton atau $0,5 \%$ dari jumlah cadangan batubara dunia menjadi pemasok utama batubara untuk China yang memiliki cadangan batubara terbukti 114,5 miliar ton atau setara $13,9 \%$ dari jumlah cadangan batubara dunia. Dengan rata-rata produksi 340 juta ton per tahun, sekitar 240 juta ton di ekspor dan cadangan terbukti batubara Indonesia akan habis dalam 20 tahun. Jika ini terjadi maka pada saatnya Indonesia terancam menjadi importir minyak dan batubara.

Di sektor migas, penguasaan cadangan migas oleh perusahaan asing masih dominan, yakni dari jumlah 225 blok migas yang dikelola kontraktor kontrak kerja sama non Pertamina, 120 blok dioperasikan perusahaan asing dan hanya 28 blok yang dioperasikan perusahaan nasional serta sekitar 77 blok dioperasikan perusahaan gabungan asing dan lokal.

Pemerintah merencanakan target porsi operator oleh perusahaan nasional mencapai $50 \%$ pada 2025 , dan saat ini porsi nasional hanya $25 \%$; sementara itu $75 \%$ dikuasai asing. Patut direnungkan bahwa dominasi asing pada sektor migas dan pertambangan itu, dengan penguasaan wilayah kerja yang meluas dari wilayah Sabang di barat sampai Papua di timur. 
Tabel 5

Beberapa Pertambangan Milik Asing di Indonesia

\begin{tabular}{|c|c|c|c|}
\hline No. & Nama Perusahaan & Wilayah & Tambang \\
\hline 1 & $\begin{array}{l}\text { PT. Indo Tambang Raya Megah, Tbk } \\
\text { Banpu Public Company Ltd. ( } 73,22 \%)\end{array}$ & $\begin{array}{l}\text { Kalimantan } \\
\text { Tengah }\end{array}$ & Batubara (5) \\
\hline 2 & $\begin{array}{l}\text { PT. Singlurus Indonesia } \\
\text { Lanna Resources Public Co. Ltd } \\
(65 \%)\end{array}$ & Kalimantan Barat & Batubara (1) \\
\hline 3 & $\begin{array}{l}\text { PT. Lamuna Harita Indonesia } \\
\text { Lanna Resource Public Co Ltd }\end{array}$ & Kalimantan Barat & $\begin{array}{l}\text { Batubara } \\
\text { (1) }\end{array}$ \\
\hline 4 & $\begin{array}{l}\text { PT. INCO } \\
\text { Vale Canada Limited (58,73\%) } \\
\text { Sumitomo Metal Mining Co Ltd } \\
(20,09 \%)\end{array}$ & Sulawesi Tengah & Nikel \\
\hline 5 & $\begin{array}{l}\text { PT. Freeport Indonesia } \\
\text { Freeport - Mc Moran Copper \& Gold } \\
\text { Corp }(81,28 \%)\end{array}$ & Papua & Emas \\
\hline 6 & $\begin{array}{l}\text { PT. Bahari Cakrawala Sebuku Straits } \\
\text { Resources Ltd (100\%) }\end{array}$ & $\begin{array}{l}\text { Kalimantan } \\
\text { Selatan }\end{array}$ & $\begin{array}{l}\text { Batubara } \\
\text { (1) }\end{array}$ \\
\hline 7 & $\begin{array}{l}\text { PT. Newmont Nusa Tenggara } \\
\text { PT. Newmont Mining Corp ( } 80 \%)\end{array}$ & $\begin{array}{l}\text { Nusa Tenggara } \\
\text { Timur }\end{array}$ & Emas \\
\hline 8 & Exxon Mobil & $\begin{array}{l}\text { Aceh; Jawa Timur } \\
\text { dan Jawa Tengah }\end{array}$ & $\begin{array}{l}\text { Industri Hulu } \\
\text { Migas }\end{array}$ \\
\hline 9 & Petro China & $\begin{array}{l}\text { Sumatera; Jawa } \\
\text { Timur; Papua }\end{array}$ & $\begin{array}{l}\text { Industri Hulu } \\
\text { Migas }\end{array}$ \\
\hline 10 & Amerada Heiss & $\begin{array}{l}\text { Sumatera; Jawa } \\
\text { Timur; Riau } \\
\text { Kepulauan }\end{array}$ & $\begin{array}{l}\text { Industri Hulu } \\
\text { Migas }\end{array}$ \\
\hline 11 & Chevron & $\begin{array}{l}\text { Sumatera; Jawa } \\
\text { Timur; Papua, } \\
\text { Kalimantan Barat; }\end{array}$ & $\begin{array}{l}\text { Industri Hulu } \\
\text { Migas }\end{array}$ \\
\hline 12 & Santos & $\begin{array}{l}\text { Riau Kepulauan } \\
\text { Jawa Timur }\end{array}$ & $\begin{array}{c}\text { Industri Hulu } \\
\text { Migas }\end{array}$ \\
\hline
\end{tabular}

Sumber : BISINFOCUS dan Situs Web Perusahaan, 2012

Perusahaan asing di Indonesia tidak saja menguasai pertambangan dan perdagangan, tetapi telah meluas dari dulu seperti sarana produksi pertanian yang meliputi benih dan obat-obatan hingga industri pengolahan, pengepakan, perdagangan, perkebunan, pertambangan hingga ritel. Liberalisasi perdagangan internasional telah memberi peluang kepada asing untuk meningkatkan pasarnya di Indonesia.

Penetrasi asing melalui perusahaan multinasional di bidang pangan semakin kuat. Pada awalnya masuk ke Indonesia melalui aktivitas perdagangan, kemudian masuk ke produksi dengan argumentasi untuk jaminan pasokan barang, dan berlanjut menguasai industri benih serta menciptakan ketergantungan dalam rangka meningkatkan volume produksi.

Hal itu saja ternyata belum cukup, perusahaan asing melangkah lebih lanjut masuk ke Industri pengolahan melalui akuisisi perusahaan nasional, bahkan untuk menjamin produknya bisa terjual, perusahaan asing juga masuk ke usaha ritel. Pada 2005, omzet ritel modern tercatat Rp.42 triliun, kemudian meningkat lagi pada 2006 menjadi Rp. 50,8 triliun, dan pada 2008 telah meningkat lagi menjadi Rp. 58,5 triliun. Pada 
2012 akan ada 3 ritel asing yang berekspansi ke Indonesia yaitu Family Mart (Korea
Selatan), Lawson (Jepang), dan Materi AG (Jerman).

\section{Tabel 6}

Perusahaan Agroindustri Dikuasai MNC

\begin{tabular}{cllcl}
\hline No. & \multicolumn{1}{c}{ Nama/Produk } & \multicolumn{1}{c}{ Investor } & Saham $(\%)$ & \multicolumn{1}{c}{ Pemilik asal } \\
\hline $\mathbf{1}$ & ABC (Kecap/Sirup/Saus) & HJ. Heinz (USA) & 65 & PT. ABC CF \\
$\mathbf{2}$ & Sari Wangi (Teh) & Unilever (BLD) & 100 & PT. Sari Wangi \\
3 & Bango (Kecap) & Unilever (BLD) & 100 & PT. Sakura AF \\
4 & Taro (Makanan Ringan) & Unilever (BLD) & 100 & PT. Rasa Murni U \\
$\mathbf{5}$ & Aqua (AMDK) & Danone (Franc) & 74 & PT. Tirta Investama \\
$\mathbf{6}$ & Hellios, Nyam-Nyam & Campbel (USA) & 100 & PT. Hellios AP \\
& (Biskuit) & & & \\
7 & Ades (AMDK) & Coca-cola (USA) & 100 & PT. Ades APS \\
8 & SGM (Susu/Makanan & Numico (Belgia) & 82 & PT. Sari Husada \\
9 & Bayi) & Philip Morris & 100 & PT. HM. \\
& Dji Sam Soe, A Mild & (USA) & & Sampoerna \\
& (Rokok) & & & \\
\hline
\end{tabular}

Sumber : BPPP Kementerian Pertanian RI, Jakarta,2012

Industri input pertanian saat ini dipatok hanya oleh 10 perusahaan MNC dengan nilai penjualan mencapai 40 miliar dollar AS, dan 5 perusahaan MNC diantaranya Monsanto, Bayer Crop, BASF AG., dan Dow Agro serta Syngenta. Sepuluh besar MNC menguasai penjualan pangan senilai 409 miliar dollar AS, dan lima diantaranya yakni Nestle, Cargill, ADM, Unilever dan Kraft Food. Indonesia juga masuk dalam cengkeraman jaringan MNC. Terutama Nestle yang terbesar menguasai perdagangan kakao dunia, Cargill menguasai perdagangan pakan ternak, dan Unilever menguasai pangan olahan. Selanjutnya ritel pangan dunia juga dikuasai MNC, diantaranya Wal Mart, Metro Group, Tesco, Seven \& I Holdings, dan Carrefour. Belum lagi produk pangan yang secara lokal mudah dijual ke perusahaan asing, diantaranya Danone (Perancis), Unilever (Belanda), Nestle (Swiss), Coca-Cola (USA), HJ. HEINZ (USA), Compbles (USA), Numico (Belanda), da Philip Morris (USA).

Dominasi asing ternyata juga terjadi di pasar perdagangan lokal, dan pangsa pasar retail asing di Indonesia senantiasa meningkat setiap tahun. Pasar modern di Indonesia tumbuh rata-rata $31,4 \%$ setiap tahun, dan tahun 2012 masuk lagi ritel asing yaitu Family Mart dan Lawsan dari Korea Selatan dan Jepang, serta Metro AG yang berpusat di Jerman. Kehadiran asing ternyata menjadi ancaman pasar tradisional dan terbukti pertumbuhannya menurun $8 \%$ di Indonesia, bahkan di Jakarta merosot 60\%; dan Malang turun hingga $30 \%$.

Tabel 7

Pangsa Pasar Retail Asing di Indonesia (\%)

\begin{tabular}{cccc}
\hline Tahun & Department Store & Supermarket & Hyper Market \\
\hline 2007 & 10,7 & 13,6 & 69,9 \\
2008 & 10,7 & 14,1 & 70,7 \\
2009 & 10,8 & 14,7 & 71,7 \\
2010 & 10,9 & 15,3 & 72,7 \\
2011 & 11,0 & 15,9 & 73,8 \\
\hline
\end{tabular}

Sumber : Business Information, 2012, diolah kembali 
Dengan populasi 236,7 juta jiwa, menjadikan Indonesia sebagai pasar yang menarik, apalagi kondisi makro ekonomi stabil, pendapatan per kapita senantiasa meningkat setiap tahun, dan Bank Dunia memperkirakan jumlah kelas menengah di Indonesia bertambah 50 juta dalam 7 tahun ini menjadi 134 juta jiwa pada 2010. Pertumbuhan kelas menengah dengan pergeseran gaya hidup menjadi target tersendiri, dan kelas menengah membutuhkan produk-produk baru yang berbeda sebagai simbol status kehidupan.

Sepanjang tahun 2011, arus waralaba asing ke Indonesia sangat banyak dan mencapai 400 waralaba asing yang bergerak dalam perdagangan makanan dan minuman serta usaha ritel kebutuhan rumah tangga; padahal usaha ini sudah lama diketahui pengusaha lokal, kehadiran Carrefour dan Giant hingga kecamatan pinggiran kota dipastikan mematikan pasar tradisional.

Tabel 8

Analisis SWOT

\begin{tabular}{|c|c|}
\hline Strength (S) & Weakness $(\mathrm{W})$ \\
\hline $\begin{array}{l}\text { 1. Memiliki modal besar } \\
\text { 2. Penggunaan teknologi dan } \\
\text { manajemen besar } \\
\text { 3. Memiliki keahlian dan manajemen } \\
\text { yang handal } \\
\text { 4. Menguasai saham mayoritas } \\
\text { 5. Dukungan negara asal } \\
\text { 6. Menguasai sektor-sektor strategis, } \\
\text { yakni perbankan, pertambangan, pasar } \\
\text { modal, retail, telekomunikasi, } \\
\text { perkebunan kelapa sawit }\end{array}$ & $\begin{array}{l}\text { 1. Kurang memiliki kepedulian } \\
\text { terhadap masyarakat sekitar } \\
\text { perusahaan } \\
\text { 2. Tidak sensitif terhadap tata budaya } \\
\text { masyarakat lokal } \\
\text { 3. Tidak transparan terhadap hasil } \\
\text { produksi dan setoran pajak } \\
\text { 4. Mayoritas laba dibawa kembali ke } \\
\text { negara asal } \\
\text { 5. Kurang peduli dengan } \\
\text { kesejahteraan buruh, dan } \\
\text { lingkungan } \\
\text { 6. Memanfaatkan kelemahan } \\
\text { peraturan perundangan Indonesia }\end{array}$ \\
\hline Opportunity $(\mathrm{O})$ & Threat $(\mathrm{T})$ \\
\hline $\begin{array}{l}\text { 1. UU No. } 4 \text { Tahun } 2009 \text { tentang } \\
\text { Pertambangan Mineral dan Batubara; } \\
\text { PP No. } 23 \text { Tahun } 2010 \text { tentang } \\
\text { Pelaksanaan Kegiatan Usaha } \\
\text { Pertambangan Mineral dan Batubara; } \\
\text { PP. No. } 7 \text { Tahun } 2012 \text { tentang } \\
\text { Peningkatan Nilai Tambah Mineral } \\
\text { 2. PP. No } 24 \text { Tahun } 2012 \text { tentang } \\
\text { Perubahan atas PP. No. } 23 \text { Tahun } \\
\text { 2010 tentang PKU PMB } \\
\text { 3. Peraturan Menteri Perdagangan } \\
\text { Nomor } 31 \text { Tahun } 2008 \text { tentang } \\
\text { Penyelenggaraan Waralaba di } \\
\text { Indonesia } \\
\text { 4. Sikap pemerintah yang menganggap } \\
\text { wajar apabila dunia usaha Indonesia } \\
\text { dikuasai pihak terkuat, termasuk asing } \\
\text { dengan alasan globalisasi, dan } \\
\text { perdagangan bebas. } \\
\text { 5. Peraturan BI yang longgar terhadap }\end{array}$ & 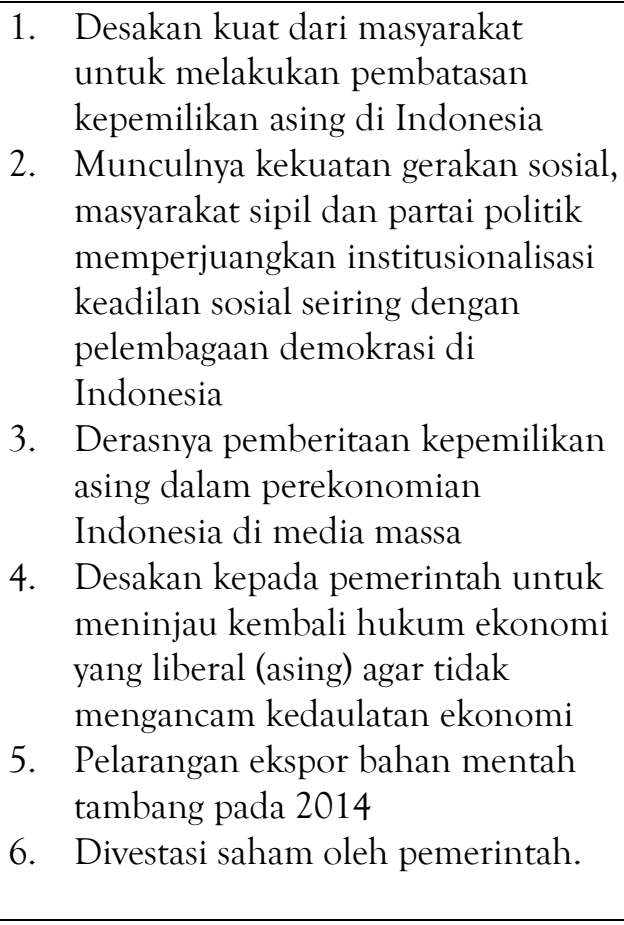 \\
\hline
\end{tabular}




\begin{tabular}{l|l}
\hline Bank Asing di Indonesia & \\
6. $\begin{array}{l}\text { Longgarnya aturan pemerintah terkait } \\
\text { perkebunan di kuasai asing seperti } \\
\text { kelapa sawit dan lahan-lahan } \\
\text { pertanian. }\end{array}$ & \\
\hline
\end{tabular}

Sumber : Peneliti, 2012

Masa depan perekonomian Indonesia cukup mengkhawatirkan dengan makin dominannya investasi kepemilikan asing dalam perekonomian nasional, seperti perbankan, migas, batubara, operator telekomunikasi, perdagangan retail, kepemilikan SBI, penguasaan perkebunan kelapa sawit, dan lain-lain. Pemerintah tampaknya tak peduli lagi dengan amanat Pasal 33 UUD 1945, dan melupakan bahwa basis kulturalis bangsa Indonesia adalah kekeluargaan dan kolektivisme. Perbankan lebih tertarik memberi kredit kepada 331 perusahaan raksasa daripada ke UMKM yang mencapai 44 juta. Rendahnya akses kredit berakibat langsung pada rendahnya daya asing industri dalam negeri. Itu sebabnya, meski pertumbuhan ekonomi Indonesia meningkat $6,5 \%$ dan pendapatan per kapita mencapai Rp. 30,8 juta pada 2011, pertumbuhan ekonomi itu tetap tidak menyentuh hidup rakyat kecil sebagaimana tercermin pada wajah petani plasma, nasib warga sekitar area tambang emas, nikel, mangan, dan batubara. Kemarahan rakyat muncul setelah melihat kenyataan penetrasi asing melalui perusahaan multinasional semakin mencengkram sarana produksi pertanian, industri pengolahan, pengepakan, perdagangan, angkutan, dan retail.

Tabel 9

Strategi Pengendalian Dominasi Kepemilikan Asing

\begin{tabular}{|c|c|}
\hline STRATEGI S - O & STRATEGI S - T \\
\hline $\begin{array}{l}\text { Melakukan tinjau ulang seluruh peraturan } \\
\text { perundang-undangan yang terkait } \\
\text { kepemilikan asing dalam sektor-sektor } \\
\text { ekonomi strategis, dan melaksanakan } \\
\text { secara konsisten untuk menghindari } \\
\text { spekulasi dan ketidakpastian. }\end{array}$ & $\begin{array}{l}\text { Melaksanakan program Corporate Social } \\
\text { Responsibility dalam rangka pembangunan } \\
\text { berkelanjutan dengan prioritas pada } \\
\text { menjaga lingkungan, peduli kepada } \\
\text { masyarakat sekitar perusahaan, dan } \\
\text { membayar pajak }\end{array}$ \\
\hline STRATEGI W - O & STRATEGI W - T \\
\hline $\begin{array}{l}\text { Mengusahakan terwujudnya semangat dan } \\
\text { praktik Indonesia Incorporated untuk selalu } \\
\text { mencapai kemajuan dengan semangat } \\
\text { kebangsaan yang kuat, dan nasionalisme } \\
\text { ekonomi yang bermanfaat bagi bangsa, } \\
\text { serta memperhitungkan cadangan SDA } \\
\text { untuk dikelola di kemudian hari. }\end{array}$ & $\begin{array}{l}\text { Kerja sama ekonomi dan investasi asing } \\
\text { terus berdasarkan semangat saling } \\
\text { membutuhkan, saling menguntungkan, } \\
\text { dan mem-berdayakan kekuatan dalam } \\
\text { negeri; negara harus terlibat aktif, } \\
\text { merencanakan dan merekayasa serta tidak } \\
\text { biarkan diurus pasar. }\end{array}$ \\
\hline
\end{tabular}

Sumber : Peneliti, 2012

Selanjutnya secara spesifik, strategi pengendalian kepemilikan asing dalam sektorsektor ekonomi strategis, yakni:

1. Pembatasan kepemilikan asing dalam perbankan hingga $51 \%$ dengan cara bertahap.
2. Pembatasan operasional waralaba asing di Indonesia dengan cara pengetatan izin impor dan setiap perusahaan hanya boleh memiliki satu angka pengenal importir umum serta diperkenankan impor barang dalam satu kategori. 
3. Pelepasan saham yang dimiliki investor asing secara bertahap di usaha pertambangan mineral dan batubara melalui divestasi saham (dana APBN).

4. Penerapan pajak ekspor pada tambang mentah, dan memperketat izin impor.

5. Membeli kembali saham-saham yang dimiliki perusahaan asing di bidang operator telekomunikasi.

6. Pembatasan kepemilikan asing dalam Sertifikat Bank Indonesia.

7. Menghentikan pinjaman luar negeri pemerintah dan mengembalikan utangutang yang sudah jatuh tempo beserta bunga setiap tahun, serta bertahan dengan anggaran berimbang.

\section{PENUTUP}

1. Kesejahteraan ekonomi dan kedaulatan ekonomi merupakan suatu ideologi, dan demokrasi ekonomi tidak harus berarti anti asing. Dalam era global, kerjasama merupakan keniscayaan, dan dibangun atas dasar ideologi yang jelas dan kukuh. Jadi asing tetap dibutuhkan dan hanya sebagai pelengkap setelah prioritas keberpihakan ditujukan pada upaya membangun kedaulatan ekonomi sesuai asas demokrasi. Nasionalisme ekonomi yang membawa kemajuan negara dan bangsa memang tidak menutup pintu untuk masuknya peran asing; hanya saja nasionalisme ekonomi membutuhkan peran pemerintah berlandaskan semangat kebangsaan yang kuat dan bisa membawa bangsanya maju sejahtera. Perkembangan sektor keuangan yang berlangsung tanpa kendali di tengah himpitan beban utang luar negeri, dan derasnya arus modal asing ke pasar modal menjadikan buble economy dan rentannya perekonomian Indonesia di masa mendatang.
2. Pertumbuhan ekonomi Indonesia sebesar 6,5\% tahun 2011 ternyata tidak banyak menyentuh sektor riil, dan perkembangan positif yang ditunjukkan indikator ekonomi makro tersebut lebih banyak dinikmati permodal dan masyarakat kalangan atas; justru masyarakat menengah ke bawah merasakan sebaliknya. Apalagi pembayaran atas pendapat perusahaan asing di Indonesia semakin besar dari tahun ke tahun, dan defisit transaksi berjalan senantiasa berlanjut karena kelas menengah masyarakat cenderung meningkatkan konsumsi barang dan jasa asing. Hendaknya penentu kebijakan mengendalikan volatilitas aliran modal, nilai kurs, pinjaman luar negeri swasta berjangka pendek, dan alokasi kredit yang produktif. Harus diupayakan modal masuk tidak didominasi oleh yang berjangka pendek. Kebijakan perlu dilakukan untuk membuat modal lebih lama tinggal di Indonesia. Jika hal ini dapat dilakukan dengan baik, maka terbuka peluang besar bagi perkembangan ekonomi Indonesia yang berkesinambungan. Kebijakan mengizinkan investor asing memiliki hingga 99\% saham perbankan nasional sudah tidak relevan lagi, ini berarti Bank Indonesia harus memiliki keberanian untuk mengubah aturan yang sudah ada untuk membatasi kepemilikan asing hanya sebesar $51 \%$ saja, dan senantiasa waspada terhadap rekayasa investor dalam sektor keuangan terhadap celahcelah regulasi. Begitu pula Bank Indonesia wajib membuat regulasi yang mampu mendorong penguatan tata kelola bank dalam rangka memelihara sentimen positif terhadap fluktuasi ekonomi. 


\section{DAFTAR PUSTAKA}

Agus Sardjono, Hukum Ekonomi Yang Liberal, Harian Kompas, Jumat, 27 Mei 2011, hal. 6.

Faisal Basri, 2009, Lanskap Ekonomi Indonesia, Kencana Persada Media Group, Jakarta.

Gita Wiryawan, Nasionalisme Ekonomi, Harian Kompas, Kamis, 17 Oktober 2010, hal. 7.

Irawan, dan M. Suparmoko, 2002, Ekonomika Pembangunan, BPFF - Yogyakarta, Yogyakarta.

Lexy J. Moleong, 2004, Metode Penelitian Kualitatif, Edisi Revisi, Remaja Rosdakarya, Bandung.

Mirza Adityaswarsa, Menyikapi Bank Milik Asing, Harian Kompas, Jumat, 10 Juni 2011, hal. 7.

Revrisond Baswir, Selamatkan Ekonomi Indonesia, Harian Kompas, Jumat, 3 Juni 2011, hal. 6.

Siswono Yudo Husodo, 66 Tahun Ekonomi Indonesia, Harian Kompas, Selasa, 23 Agustus 2011, hal. 7.

Umar Juoro, Masa Depan Ekonomi Indonesia, Harian Kompas, Jumat, 2 September 2011, hal. 6.

Zaenal Abidin, Bank Asing dan Peranan BI, Harian Kompas, Senin, 20 Juni 2011, hal. 7. 


\section{JURNAL ILMIAH}

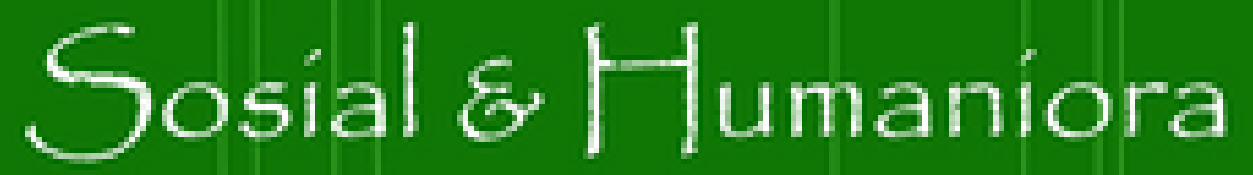

JOLRNA OF GMLAL S HLMLANT

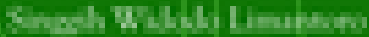

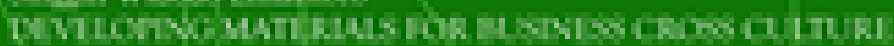

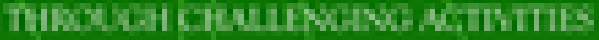

Bth Itanth

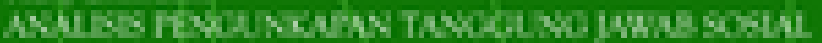

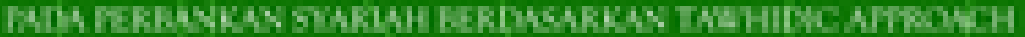

Dirknthes

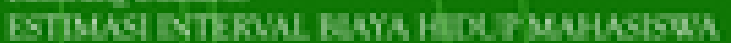

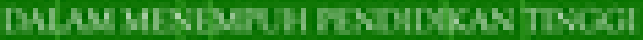

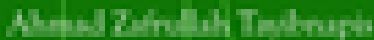

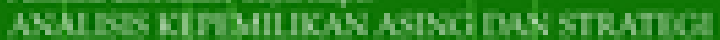

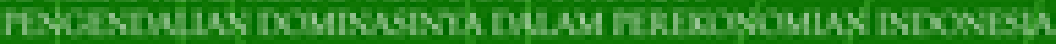

Bif

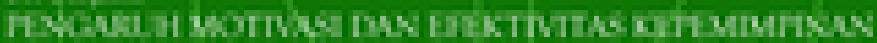

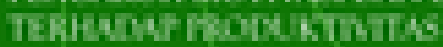




\section{ARTICLES}

DEVELOPING MATERIALS FOR BUSINESS CROSS CULTURE THROUGH CHALLENGING ACTIVITIES

Singgih Widodo Limantoro

园 PDF

ANALISIS PENGUNKAPAN TANGGUNG JAWAB SOSIAL PADA PERBANKAN SYARIAH BERDASARKAN TAWHIDIC APPROACH

Rizky Eriandani

Q

ESTIMASI INTERVAL BIAYA HIDUP MAHASISWA DALAM MENEMPUH PENDIDIKAN TINGGI

Bambang Budiarto

Q

ANALISIS KEPEMILIKAN ASING DAN STRATEGI PENGENDALIAN DOMINASINYA DALAM PEREKONOMIAN INDONESIA

Ahmad Zafrullah Tayibnapis

20 PDF

PENGARUH MOTIVASI DAN EFEKTIVITAS KEPEMIMPINAN TERHADAP PRODUKTIVITAS

Sri Sarjana 